\title{
PENGARUH PENGGUNAAN KONTRASEPSI HORMOPNAL TERHADAP TEKANAN DARAH PADA AKSEPTOR KB DI KOTA SAMARINDA
}

\author{
Azka Rafia, Adam M Ramadhan, Rolan Rusli* \\ Laboratorium Penelitian dan Pengembangan Farmaka Tropis \\ Fakultas Farmasi Universitas Mulawarman \\ *email : rolan@farmasi.unmul.ac.id
}

\begin{abstract}
ABSTRAK
Indonesia merupakan negara berkembang dengan berbagai jenis masalah yang dihadapi salah satunya adalah tingginya pertumbuhan penduduk. Untuk mengatasi masalah tersebut pemerintah membentuk program keluarga berencana(KB). Salah satu jenis program KB adalah kontrasepsi hormonal. Kontrasepsi hormonal dapat mempengaruhi kesehatan akseptor KB, salah satunya mempengaruhi tekanan darah. Penelitian ini bertujuan untuk mengetahui pengaruh penggunaan kontrasepsi hormonal terhadap tekanan darah akseptor KB. Penelitian ini merupakan penelitian analitik dengan pendekatan kohort retrospektif dilakukan pada 139 responden yang dipilih dengan cara random sampling. Metode pengumpulan data dilakukan dengan wawancara untuk mengetahui karakteristik pasien dan analitik untuk mengetahui tekanan darah awal dan akhir akseptor KB. Hasil dari penelitian ini menunjukkan bahwa rata-rata tekanan darah awal sebesar 103/74.78 $\mathrm{mmHg}$ dan tekanan darah akhir sebesar 110/75.22 mmHg. Kontrasepsi hormonal memberikan pengaruh pada kenaikan tekanan darah.
\end{abstract}

Kata Kunci : Kontrasepsi Hormonal, Pil, Suntik, Tekanan Darah

\begin{abstract}
Indonesia is a developing country with various types of problems faced one of which is the high population growth. To overcome these problems the government formed a family planning program $(K B)$. One type of family planning programs is hormonal contraception. hormonal contraception can affect the health of family planning acceptors, one of which affects blood pressure. This study aims to determine the effect of hormonal contraception use on blood pressure acceptors. This study is a retrospective cohort analytic approach conducted on 100 respondents were selected by random sampling. Methods of data collection is done by interviews to determine the characteristics of patients and observation to determine the beginning and the end of the blood pressure acceptors. The results of this study showed that the average initial blood pressure of $103 / 74.78 \mathrm{mmHg}$ and final blood pressure of $110 / 75.22 \mathrm{mmHg}$. Hormonal contraception influence on the increase in blood pressure.
\end{abstract}

Keyword : blood pressure, hormonal contraception 


\title{
PENDAHULUAN
}

Keluarga Berencana (KB) merupakan bagian integral dari pembangunan nasional yang bertujuan melembagakan "Keluarga Berkualitas". Program KB ini sudah merupakan suatu keharusan dalam upaya menanggulangi pertumbuhan penduduk dunia umumnya dan penduduk Indonesia khususnya. Berhasil tidaknya dan program KB ini juga akan menentukan kesejahteraan bangsa Indonesia (Setyarini, 2015).

Perubahan tekanan darah tinggi dapat terjadi pada $5 \%$ pemakaian kontrasepsi hormonal. Tekanan darah akan meningkat secara bertahap dan tidak akan menetap. Wanita yang memakai kontrasepsi selama 5 tahun atau lebih, frekuensi perubahan tekanan darah tinggi meningkat 2 sampai 3 kali dari pada tidak memakai alat kontrasepsi hormonal. Resiko terjadinya tekanan darah tinggi akan meningkat dengan bertambahnya umur, lama pemakaian kontrasepsi dan bertambahnya berat badan (Dewi dan Familia, 2010). Wanita yang memakai kontrasepsi hormonal alami peningkatan tekanan darah sistolik dan diastolik terutama pada 2 tahun pertama penggunaannya. Tidak pernah ditemukan terjadi peningkatan yang patologik karena jika memakai kontrasepsi dihentikan, biasanya tekanan darah akan kembali normal (Baziard, 2002). Pada akseptor KB suntik, lama penggunaan 6 bulan-1 tahun sudah meningkatkan tekanan darah akseptor $20 \mathrm{mmHg}$. Setelah penggunaan $1-5$ tahun dan $>5$ tahun peningkatan tekanan darah akseptor ada yang mencapai $40 \mathrm{mmHg}$. Akseptor yang mengalami peningkatan tekanan darah hingga $40 \mathrm{mmHg}$ rata-rata berumur 33-45 tahun. pemakaian kontrasepsi hormonal pil akan dapat memicu meningkatnya tekanan darah 4-5\% pada wanita yang pada awalnya mempunyai tekanan darah normal.

\section{METODE PENELITIAN}

\begin{abstract}
Alat dan Bahan
Alat yang digunakan pada penilitian ini adalah timbangan, tensimeter,laptop dan bulpoint. Bahan yang digunakan dalam penelitian ini adalah lembar persetujuan menjadi responden, lembar pengumpumpulan data dan kartu akseptor KB.

\section{Prosedur Penelitian}

Dilakukan observasi ke klinik dan puskesmas untuk mengetahui populasi dan didapatkan sampel penelitian. Pemberian perlakukan dapat dilakukan setelah semua persyaratan terpenuhi. Diberikan diawal penelitian dimulai lembar Informed Consent bertujuan sebagai kode etik dalam melaksanakan penelitian, diberikan surat persetujuan bahwa pasien siap mengikuti prosedur penelitian ini serta pemberian lembar data pasien untuk mengetahui karakteristik pasien. Selain itu, diukur tekanan darah pada pasien dan dicatat tekanan darah pasien saat data dan tekanan darah sebulan sebelumnya yang dapat dilihat dari kartu akseptor KB. Jenis penelitian ini adalah penelitian analitik dengan pendekatan kohort retrospektif dengan metode random sampling.
\end{abstract}

\section{HASIL DAN PEMBAHASAN}

\section{Karakteristik akseptor KB}

\section{Pendidikan}

Hasil penelitiaan diperoleh 139 wanita yang menggunakan kontrasepsi hormonal sebagai responden penelitian yang telah memenuhi kriteria inklusi. Wanita pengguna kontrasepsi hormonal ini berusia berkisar 21-42 tahun dimana usia ini masih merupakan kategori usia subur bagi wanita. 
Tabel 2 Distribusi Akseptor KB Berdasarkan Pendidikan

\begin{tabular}{lll}
\hline Pendidikan & Jumlah (Orang) & Persentase \\
\hline SD & 3 & $2,16 \%$ \\
SMP & 8 & $5,78 \%$ \\
SMA & 99 & $71,29 \%$ \\
SMK & 4 & $2,88 \%$ \\
D3 & 18 & $12,50 \%$ \\
S1 & 7 & $5,03 \%$ \\
\hline
\end{tabular}

Karakteristik akseptor KB yang berada di salah satu klinik dan puskesmas di Kota Samarinda seperti terlihat pada (Tabel 1) akseptor KB yang berpendidikan SD sebesar 2,16\%, SMP sebesar 5,78\%, SMA sebesar 71,29\%, SMK sebesar 2,88\%, D3 sebesar 12, $55 \%$ dan S1 sebesar 5,03\%. Jumlah responden berpendidikan SD sebanyak 3 orang, berpendidikan SMP sebanyak 8 orang, berpendidikan SMA sebanyak 99 orang, berpendidikan SMK sebanyak 4 orang, berpendidikan D3 sebanyak 18 orang dan berpendidikan S1 sebanyak 7 orang. Dari data yang diperoleh dapat diketahui bahwa akseptor terbanyak adalah berpendidikan SMA.

Pendidikan merupakan bagian terpenting dalam kehidupan manusia. Suatu desa dikatakn maju apabila memiliki sumber daya manusia (SDM) yang baik. Pendidikan yang baik maka akan mempengaruhi sebuah keluarga terutama dalam membentuk keluarga berencana. Hasil pengamatan Erista (2015) memperlihatkan bahwa Akseptor KB lebih banyak yang berpendidikan SMP dibandingkan dengan jenjang pendidikan yang lain. Data yang didapatkan tidak sejalan dengan penelitian tersebut karena pada salah satu klinik dan puskesmas di Kota Samarinda didapatkan bahwa akseptor KB terbesar adalah yang berpendidikan SMA. Pendidikan ini dapat mempengaruhi pemilihan dari jenis kontrasepsi hormonal yang akan digunakan. Selain itu juga pendidikan berpengaruh terhadap kesadaran dari akseptor KB untuk mengikuti program berencana dan rutin mengggunakan kontasepsi.

\section{Pekerjaan}

Muhcin, dkk (2010) menyatakan bekerja merupakan kewajiban manusia dalam memuliakan dan merupakan gerak daripada badan dan pikiran setiap orang guna memelihara kelangsungan hidup badaniah dan rohaniah untuk menghasilkan barang atau jasa guna memuaskan kebutuhan masyarakat. Karakteristik akseptor KB yang berada di salah satu klinik dan puskesmas di Kota Samarinda berdasarkan pekerjaan terlihat seperti (Tabel 2). Terdapat IRT sebesar 49\%, Wiraswasta sebesar 12\% dan PNS sebesar 39\%. Responden sebagai IRT sebanyak 68 orang, sebagai wiraswasta sebanyak 17 orang dan sebagai PNS sebanyak 54 orang. Tetapi penelitian ini tidak sesuai dengan teori tersebut. Karena wanita pada penelitian ini menggunakan kontrasepsi sesuai kemauannya sendiri dan dipengaruhi oleh lingkungan sekitar. Menurut teori lebih banyak wanita karir yang menggunakan kontrasepsi karena ingin fokus dengan karimya tanpa diganggu dengan pekerjaan dapat berpengaruh terhadap tekanan darah. Jika pekerjaan masih batas normal sekitar 7 jam sehari maka pekerjaan tersebut dapat menormalkan tekanan darah atau menurunkan tekanan darah karena adanya aktivitas yang dilakukan. Tekanan darah lebih meningkat pada seseorang yang kurang beraktivitas. Sedangkan jika bekerja melebihi batas normal yaitu lebih dari 7 jam maka pekerjaan tersebut dapat meningkatkan tekanan darah dikarenakan tubuh yang dipaksa bekerja keras dan otak dipaksa untuk berpikir terlalu lama sehinggga hal itu dapat meningkatakan tekanan darah seseorang. Gaya hidup dihubungkan dengan kejadian hipertensi, dimana gaya hidup dibagi menjadi beberapa variabel yaitu aktivitas fisik, kegiatan rumah tangga, serta kebiasaan makan sehari-hari dan fast food. Dalam penelitian 
tersebut menunjukkan bahwa variabel aktivitas fisik, kegiatan rumah tangga, serta kebiasaan makan berhubungan dengan kejadian hipertensi. Dimana semakin berat aktivitas fisik dan tugas rumah tangga maka pada penderita hipertensi beresiko untuk menderita hipertensi ringan. Kardi (2004) aktivitas fisik yang dilakukan secar rutin akan mengurangi resiko penumpukan lemak pada dinding pembuluh darah yang akhirnya akan menjaga elastisitasnya. Dapat disimpulkan bahwa ada kecenderungan tekanan darah lebih tinggi dan frekuensi denyut nadi lebih cepat pada responden yang jarang memiliki aktivitas.

Tabel 2 Distribusi Akseptor KB berdasarkan Pekerjaan

\begin{tabular}{lll}
\hline Pekerjaan & Jumlah (Orang) & Persentase \\
\hline IRT & 68 & $49 \%$ \\
Wiraswasta & 17 & $12 \%$ \\
PNS & 54 & $39 \%$ \\
\hline
\end{tabular}

\section{Paritas}

Paritas merupakan jumlah anak yang dilahirkan oleh ibu. Anak merupakan penerus keturunan bagi keluarga sehingga di masyarakat umumnya memiliki anak lebih dari satu (Suwanti, 2014). Karakteristik akseptor KB yang berada di salah satu klinik dan puskesmas di Kota Samarinda berdasarkan paritas diketahui terlihat seperti (Tabel 3). Responden yang memiliki jumlah anak 1 sebesar 15,8\%, jumlah anak 2 sebesar $41 \%$, jumlah anak 3 sebesar $33,1 \%$, jumlah anak 4 sebesar 9,4\% dan jumlah anak 5 sebesar $0,72 \%$. Responden yang memiliki jumlah anak 1 sebanyak 22 orang, memiliki jumlah anak 2 sebanyak 57 orang, memiliki jumlah anak 3 sebanyak 46 orang, memiliki jumlah anak 4 sebanyak 13 orang dan memiliki jumlah 5 anak sebanyak 1 orang. Suwanti (2014) yang mengatakan bahwa pada umumnya ibu memiliki lebih dari 1 anak. Dapat diketahui dari data bahwa responden terbanyak memiliki jumlah anak 2. Hasil ini dapat terjadi diakibatkan oleh beberapa faktor salah satunya yaitu responden mengikuti program pemerintah yaitu program keluarga berencana (KB) dimana slogan dari program ini adalah "2 Anak Lebih Baik". Keluarga Berencana (KB) menurut Undang - Undang no 10 tahun 1992 adalah upaya peningkatan kepedulian masyarakat dalam mewujudkan keluarga kecil yang bahagia sejahtera (Anggraini, 2012).Faktor lain dapat disebabkan responden merasa 2 anak sudah cukup dan mewakili jumlah anak. Jumlah anak memperlihatkan keefektifan dari kontrasepsi yang digunakan. Jumlah anak yang banyak menunjukkan kurang efektifnya pengggunaan dari kontrasepsi. Selain itu, jumlah anak juga dapat mempengaruhi tekanan darah responden. Dimana semakin banyak anaka dapat meningkatkan tekanan darah responden karena responden cenderung lebih banyak berpikir dan lebih banyak yang dilakukan dan diurus sehingga dapat meningkatkan tekanan darah dari responden walaupun tidak banyak.

Tabel 3 Distribusi Akseptor KB berdasarkan Jumlah Anak

\begin{tabular}{lll}
\hline Jumalah Anak & Jumlah (Orang) & Persentase \\
\hline 1 & 22 & $15,80 \%$ \\
2 & 57 & $41 \%$ \\
3 & 46 & $33,10 \%$ \\
4 & 13 & $9,40 \%$ \\
5 & 1 & $0,72 \%$ \\
\hline
\end{tabular}




\section{Riwayat Hipertensi}

Karakteristik akseptor KB yang berada di salah satu klinik dan puskesmas di Kota Samarinda berdasarkan riwayat hipertensi telihat seperti (Tabel 4). Berdasarkan riwayat hipertensi didapatkan bahwa akseptor KB yang memiliki riwayat hipertensi sebesar 2,2\% dan yang tidak memiliki riwayat hipertensi sebesar 97,8\% yang menunjukkan bahwa akseptor KB lebih besar yang tidak memiliki riwayat hipertensi. Responden dengan riwayat hipertensi sebanyak 3 orang dan responden tidak memiliki riwayat hipertensi sebanyak 139 orang.

Tabel 4. Distribusi Akseptor KB berdasarkan Riwayat Hipertensi

\begin{tabular}{lll}
\hline Riwayat Hipertensi & Jumlah (Orang) & Persentase \\
\hline Ada & 3 & $2,20 \%$ \\
Tidak Ada & 136 & $97,80 \%$ \\
\hline
\end{tabular}

\section{Riwayat Merokok}

Karakteristik akseptor KB yang berada di salah satu klinik dan puskesmas di Kota Samarinda berdasarkan riwayat merokok terlihat seperti (Tabel 5). Berdasarkan riwayat hipertensi didapatkan bahwa akseptor KB yang memiliki riwayat merokok hipertensi sebesar $0 \%$ dan yang tidak memiliki riwayat hipertensi sebesar $100 \%$ yang menunjukkan bahwa akseptor KB lebih besar yang tidak memiliki riwayat hipertensi. Responden dengan riwayat merokok tidak ada dan responden tidak memiliki riwayat hipertensi sebanyak 139 orang. Dari data dapat diketahui bahwa responden tidak ada yang merokok sehingga tidak mempengaruhi tekanan darah.

Nikotin pada rokok menyebabkan meningkatkan penggumpalan darah dalam pembuluh darah sehingga pembuluh darah mengalamin penyempitan. Karena penyempitan pembuluh darah yang terjadi darah tidak dapat diedarkan dengan baik sehingga mengakibatkan peningkatan tekanan darah. Selain itu merokok juga menyebabkan peningkatan sekresi kelenjar adrenalin yang pada gilirannya menaikkan tekanan darah. Selain nikotin dalam rokok mengandung karbon monoksida yang mana peran serta karbonmonoksida dalam meningkatkan tekanan darah yaitu dapat menggantikan oksigen dalam darah dan memaksa jantung memenuhi kebutuhan oksigen tubuh sehingga menyebabkan peningkatan tekanan darah (Dewi, 2010).

Tabel 5. Karakteristik Akseptor KB berdasarkan riwayah merokok

\begin{tabular}{lll}
\hline Riwayat Merokok & Jumlah & Persentase \\
\hline Ada & 0 & $100,00 \%$ \\
Tidak Ada & 136 & $0,00 \%$ \\
\hline
\end{tabular}




\section{Pengaruh Kontrasepsi Hormonal Terhadap Tekanan Darah}

Rata-rata tekanan darah awal akseptor KB sebesar 106/70 mmHg menjadi 121/80 mmHg. Terlihat seperti (Tabel 6) tekanan darah sistol mengalami peningkatan dari 106 menjadi 121. Sama halnya dengan tekanan darah sistol, tekanan darah diastol juga mengalami peningkatan yaitu dari 70 menjadi 80. Dapat diketahui bahwa penggunaan kontrasepsi hormonal ini dapat mempengaruhi tekanan darah responden dengan meningkatkan tekanan darah. Kontrasepsi hormonal yang diperkirakan karena reaksi terhadap estrogen yang didalamnya meningkatkan kadar substrat renin. Substrat rennin (protein plasma) adalah suatu globulin yang disebut bahan renin (angiotensinogen) untuk melepaskan angiotensi I. Angiotensi I memiliki sifat vasokonstriktor yang ringan sehingga dalam beberapa detik setelah pembentukan angiotensi I maka terbentuklah angiotensi II. Selama angiotensi II dalam darah, maka mempunyai pengaruh sebagai vasokonstriksi pada arterio dalam darah yang dapat meningkatkan tahanan perifer sehingga mengakibatkan terjadinya peningkatkan tekanan arteri, dimana tekanan arteri inilah yang akan mempengaruhi peningkatan tekanan darah pada seseorang pada saat dilakukan pemeriksaan dengan tensimeter (Baziard, 2002).

Tabel 6. Rata-Rata Tekanan Darah Akseptor KB

\begin{tabular}{llll}
\hline \multicolumn{2}{l}{$\begin{array}{l}\text { Rata-rata TD Sistolik (mmHg) } \\
\text { Awal }\end{array}$} & Rkhir & Rata-rata TD Diastolik (mmHg) \\
& 121 & Awal & Akhir \\
\hline 106 & 130 & 85 \\
\hline
\end{tabular}

Tabel 7. Tekanan Darah Akseptor KB Pil dan Suntik

\begin{tabular}{lllll}
\hline \multirow{2}{*}{ Jenis Kontrasepsi } & \multicolumn{2}{l}{ TD Sistolik $(\mathrm{mmHg})$} & \multicolumn{2}{l}{ TD Diastolik $(\mathrm{mmHg})$} \\
& Awal & Akhir & Awal & Akhir \\
\hline Pil & 106 & 130 & 71 & 80 \\
Suntik & 106 & 115 & 70 & 85 \\
\hline
\end{tabular}

Tabel 8. Paired Sample Test

\begin{tabular}{|l|l|l|l|l|l|l|}
\hline & \multicolumn{2}{|l|}{ Paired Differences } & & & Sig. (2- \\
\cline { 2 - 8 } & Mean & Std.Deviation & Std. Errror Mean & $\mathrm{t}$ & Df & $\begin{array}{l}\text { Sig. } \\
\text { tailed) }\end{array}$ \\
\hline Sistol P_Sistol S & 15.9574 & 15.27424 & 2.222798 & 7.162 & 46 & .000 \\
\hline Diastol P_Diastol P & 7.87234 & 11.96665 & 1.74552 & 4.510 & 46 & .000 \\
\hline
\end{tabular}


Tekanan darah pada akseptor KB pil dan suntik terlihat seperti (Tabel 6). diketahui bahwa tekanan darah akseptor $\mathrm{KB}$ pil sebelumnya sebesar 106/70 $\mathrm{mmHg}$ dan setelah menggunakan KB pil menjadi 130/85 mmHg. Sedangkan pada KB sunti tekanan darah awal sebesar 106/70 mmHg menjadi 10/85 mmHg. Dari data dapat diketahui bahwa kedua jenis kontrasepsi ini berpengaruh terhadap tekanan darah. Dimana keduanya mengalami peningkatan. Menurut data yang ada juga dapat diketahui bahwa KB pil lebih meningkatkan tekanan darah dibandingkan dengan KB suntik. Sedangkan menurut dara statistik (Tabel 8) dapat diketahui bahwa didapatkan nilai sig Sistol P_Sistol S sebesar (0.000) lebih kecil dari (0.05) yang berarti data memiliki perbedaan. Dimana sistol dari KB pil dan sistol dari KB suntik memiliki perbedaan rata-rata. Hal ini diperkuat dengan data yang terlihat seperti (Tabel 7). Sedangkan data statistik pada tekanan darah diastol terlihat seperti (Tabel 8) didapatkan bahwa nilai sig diastol $P_{-}$diastol $S$ sebesar (0.00) lebih kecil dari (0.05) yang menunjukkan adanya perbedaan antara tekanan darah diastol pil dan tekanan darah diastol suntik.

\section{KESIMPULAN}

Berdasarkan penelitian yang telah dilakukan dapat disimpulkan bahwa:

1. Penggunaan Kontrasepsi pil dan suntik di salah satu klinik dan puskesmas di Kota Samarinda sebesar 33,8\% dan 66,2\%. Karakteristik pendidikan yaitu SMA sebesar 71,29\%. Karakteristik pekerjaan terbesar adalah SMA sebesar 49\%

2. Tekanan darah rata-rata responden sebelum dan sesudah penggunaan kontrasepsi sebesar 106/70 mmHg dan 121/80 mmHg.

3. Kontrasepsi yang paling berpengaruh terhadap tekanan darah adalah konmtrasepsi jenis pil.

\section{SARAN}

Perlu dilakukan pengukuran berat badan sebelum dan sesudah penggunaan kontrasepsi hormonal, pengukuran tekanan darah setiap hari dan pengukuran tinggi badan agar diperoleh hasil penelitian yang lebih komprehensif mengenai pengaruh kontrasepsi terhadap tekanan darah.

\section{DAFTAR PUSTAKA}

Baziad, A. 2002. Kontrasepsi Hormonal. Jakarta : PT Bina Pustaka.

Dewi, S. dan Familia, D. 2010. Hidup Bahagia Dengan Hipertensi. Yogyakarta: A Plus Books.

Kardi. 2004. Perbedaan Tekanan Darah Wanita Usia Lanjut yang Mengikuti Senam Lanjut Usia dan Tidak Mengikuti Senam Lanjut Usia di Desa Semawung, Kabupaten Purworejo, Semarang: Universitas Diponegoro.

Mardiani. 2000. Hubungan Komponen Gaya Hidup Dengan Kejadian Hipertensi. Bandung.

Muchsin, B., Sulthon, M., \& Wahid, A. (2010). Pendidikan Islam Humanistik: Alternatif Pendidikan Pembebasan Anak. Bandung: PT Refika Aditama. 
Setyarini, D. I. 2015. Lama Penggunaan Depo Medroksi Progesteron Asetat (DMPA) dan Indeks Massa Tubuh (IMT) Akseptor Kontrasepsi Suntik. Jurnal Informasi Kesehatan Indonesia. Vol. 1. No. 1 (8-16). 